\title{
Synthesis and Application of New Ruthenium Dye Containing 9,9-[di-(2-ethylhexane]-4,5-diazafluorene Ligand
}

\author{
Yanchun Ma \\ Editorial Department of Educational Institute of Jilin Province \\ Changchun 130022, China \\ Ying Gao, Yupeng Wang, Yunhui Li \& Xiuyun Yang (Corresponding author) \\ School of Chemistry and Environmental Engineering \\ Changchun University of Science and Technology \\ Changchun 130022, China \\ E-mail: yangxiuyun@cust.edu.cn
}

Received: April 12, 2011

Accepted: June 15, 2011

doi:10.5539/mas.v5n4p232

\begin{abstract}
The traditional organic ruthenium dyes have some disadvantages, such as the routes of the synthesis of ligands being too time-consuming, the separation and purification of the ligands being difficult, the lower photo-electric conversion efficiency and so on. In view of these disadvantages, we designed and synthesized a new 9,9-[di-(2-ethylhexane]-4,5-diazafluorene ligand. Then we got the dye-sensitized solar cell using this ligand. Such ruthenium dye contains a kind of derivative of 4,5-diazafluorene ligand, and comparing with the traditional bipyridine ligands, the synthetic route is more simple and it's suitable for large-scale practical application. The short-circuit current (Jsc), open-circuit voltage(Voc), fill factor (ff) and photoelectric conversion efficiency $(\eta)$ of the prepared dye-sensitized solar cell is $14.75-15.02 \mathrm{~mA} / \mathrm{cm}^{2}, 681-696 \mathrm{mV}, 0.66-0.70,6.8-7.0 \%$ respectively, when measured in the standard AM 1.5 simulated sunlight.
\end{abstract}

Keywords: 4,5-diazafluorene ligand, Dye-sensitized solar cell, Ruthenium dye

The solar energy is the most ideal clean energy in multitudinous renewable energy undoubtly, and it may meet the needs of production and life of people. At present, among numerous kinds of solar cells, the silicon solar cell has occupied the main share of solar cell market depending on its high conversion rate and mature technology. However, the silicon solar cell's operating cost is high and it is difficult to further enhance the efficiency of it. Besides, its raw materials is expensive. So the silicon solar cell's popularization is hard.

In 1991, professor Grätzel coming from Swiss Federation Senior Engineer had reported highly effective dye-sensitized solar cell . (Brian O'regan, 1991) Dye-sensitized solar cell's photo-electricity conversional efficiency has been closed to that of the silicon solar cell after more than ten years's unceasing research. More importantly, the production cost of dye-sensitized solar cell is only 1/10 to the cost of the silicon solar cell. So the dye-sensitized solar cell has a good application prospect and it will substitute for the silicon cell to occupy the solar cell market in the future. The dye-sensitized solar cell having a photo-electricity conversional efficiency of $11 \%$ had been reported. ( Nazeeruddin M. K., 2005; Grätzel M., 2008; Su H. C., 2008) But the synthetic route of traditional organic ruthenium dye ligand is time-consuming and it is difficult to purify.(Wang P., 2003)In addition, the photo-electricity conversion efficiency of organic ruthenium dye is insufficient. (Gao F. F., 2008) In order to solve the above problems, in this article, we have designed and synthesized a new kind of ligand which includes the 4,5-diazafluorene and furtherly, we have done the application of it in the dye-sensitized solar cell. The synthetic routes of the ligand and the ruthenium dye are shown in Scheme 1 and Scheme 2.

\section{Experimental section}

\subsection{Experimental apparatus and reagents}

Reagents used in the experiment are all AR; Perkin-Elmer2400 Element analyzer; Nicolet Impact -401 Infrared spectrometer; $\mathrm{KBr}$ presser; Varian Mercury $400 \mathrm{MHz}$ nuclear magnetic resonance spectrometer (solvent $\mathrm{CD}_{3} \mathrm{OD}$ ); Ultra high performance liquid chromatography/quadrupole stem tandem mass spectrometry; UPLC/ESI-MS-MS

\subsection{The synthesis of 9,9-[di-(2-ethylhexane]-4,5-diazafluorene (dedaf) ligands}

1.2.1 The synthesis of 9H-4,5-Diazafluoren-9-ketone (a) (Plater M. J., 2000)

1,10-Phenanthroline monohydrate $(5.0 \mathrm{~g}), \mathrm{KOH}(5.0 \mathrm{~g})$ and $350 \mathrm{~mL}$ water were added into the $1000 \mathrm{~mL}$ three-neck flask, heat the mixture while stirring until to it become dissolved, refluxing for 5 minutes. Then make $\mathrm{KMnO}_{4}(12.5 \mathrm{~g})$ dissolved in hot water drop into the round bottom flask, and continue to heat to reflux for three 
hours. After finishing the reaction, the mixture was extracted with $\mathrm{CHCl}_{3}$ three times and dry over anhydrous $\mathrm{MgSO}_{4}$. After rotary evaporation solvent under a reduced pressure, the crude was purified by column chromatography with ethyl acetate as eluent to afford the title product $(3.0 \mathrm{~g}$, yield $60 \%$; 55\% yield of the literature). Elemental analysis [\%, $\mathrm{C}_{11} \mathrm{H}_{6} \mathrm{~N}_{2} \mathrm{O}$ calculated] C, 72.52 (72.48), H, 3.32 (3.26), N, 15.38 (15.40).

\subsubsection{The Synthesis of 9H-4,5-diazafluoren (b) ( Wang P., 2003)}

The 9H-4,5-Diazafluoren-9-ketone (4.0 g), $\mathrm{KOH}(4.0 \mathrm{~g})$ dissolved in $150 \mathrm{ml}$ ethylene glycol were added into the $500 \mathrm{~mL}$ three-neck flask under Ar. Heating the mixture to reflux ,then $6 \mathrm{~mL} \mathrm{NH}_{2} \mathrm{NH}_{2}$ was injected for three times and reflux for 4 hours. After finishing the reaction, the mixture was extracted with $\mathrm{CH}_{2} \mathrm{Cl}_{2}$ and dry over anhydrous $\mathrm{MgSO}_{4}$. After rotary evaporation solvent under a reduced pressure, the crude was purified by column chromatography with ethyl acetate as eluent to afford the white powder product( $1.6 \mathrm{~g}, 43.3 \%$ yield) Elemental analysis [\%, $\mathrm{C}_{11} \mathrm{H}_{8} \mathrm{~N}_{2}$ calculated] $\mathrm{C}, 78.55$ (78.50), H, 4.79 (4.76), N, 16.66 (16.73).

\subsubsection{Synthesis of 9,9-[di-(2-ethylhexane]-4,5-diazafluorene (dedaf) ligand (c) ( Su H. C., 2008)}

9H-4,5-diazafluoren $(2.0 \mathrm{~g})$ was dissolved in $10 \mathrm{~mL}$ THF, $\left(\mathrm{CH}_{3}\right)_{3} \mathrm{COK}(0.53 \mathrm{~g})$ and 1-Bromo-2-ethylhexane $(0.71 \mathrm{~g})$ was added into the above THF solution. The mixture was stirred for 4 hours under room temperature. After rotary evaporation solvent THF under a reduced pressure, the crude was extracted with $\mathrm{CH}_{2} \mathrm{Cl}_{2}$, and then column chromatography with ethyl acetate/petroleum ether (1/1) as element to afford the colorless oily product $(0.28 \mathrm{~g}) .{ }^{1} \mathrm{H}$ NMR $\left(400 \mathrm{MHz}, \mathrm{CD}_{3} \mathrm{Cl}_{3}, \mathrm{H}\right): 8.70(\mathrm{~d}, 1 \mathrm{H}), 7.75(\mathrm{~d}, 1 \mathrm{H}), 7.28(\mathrm{~d}, 1 \mathrm{H}), 2.01(\mathrm{~m}, 2 \mathrm{H}), 0.67 \sim 0.91(\mathrm{~m}$, $11 \mathrm{H}), 0.47 \sim 0.51(\mathrm{~m}, 4 \mathrm{H}) .{ }^{13} \mathrm{C}$ NMR $\left(150 \mathrm{MHz}\right.$, DMSO-d $\left._{6}, \mathrm{C}\right): 158.62,149.53,131.51,122.25,51.16,43.68$, $34.53,33.86,28.01,26.95,22.56,13.87,10.12$. Elemental analysis [\%, $\mathrm{C}_{27} \mathrm{H}_{40} \mathrm{~N}_{2}$ calculated] $\mathrm{C}, 82.60(81.55), \mathrm{H}$, 10.27 (10.24), N,7.13 (7.19).

\subsection{Synthetic of the dye}

$\left.\mathrm{RuCl}_{2}(\mathrm{p} \text {-cymene })_{2}\right]_{2}(0.2106 \mathrm{~g}, 0.344 \mathrm{mmol})$ and 4,4 '- dicarboxylic acid 2,2'- bipyridine $(0.167 \mathrm{~g}, 0.688 \mathrm{mmol})$ were dissolved in DMF $(40 \mathrm{~mL})$. The mixture was stirred at $70{ }^{\circ} \mathrm{C}$ for 4 hours under Ar. Subsequently, 9,9-[di-(2-ethylhexane]-4,5-diazafluorene (dedaf) ligand $(0.27 \mathrm{~g}, 0.688 \mathrm{mmol})$ was added into the flask and the reaction mixture was stirred at $140^{\circ} \mathrm{C}$ for 4 hours. At last, an excess of $\mathrm{NH}_{4} \mathrm{NCS}(2.09 \mathrm{~g}, 27.50 \mathrm{mmol})$ was added to the resulting solution and the reaction was continued for another 4 hours at the same temperature. The solvent was removed on a rotary evaporator; $30 \mathrm{ml}$ water was added to obtain a suspended solution. The solid was collected through suction filtration, washed with water and ether, and dried under a vacuum. The crude was dissolved in methanol solution of $\mathrm{NaOH}(0.05 \mathrm{M})$ and purified on a Sephadex LH-20 column. The collected main band was concentrated and slowly titrated with an acidic water solution $\left(\mathrm{HNO}_{3}\right)$ to $\mathrm{PH}$ 4.2. The precipitate was collected and dried in air. The molecular structure (I) of title ruthenium dye $\left(\mathrm{C}_{41} \mathrm{H}_{48} \mathrm{~N}_{6} \mathrm{O}_{4} \mathrm{RuS}_{2}\right)$ : yield $75 \%$. ${ }^{1} \mathrm{H}$ NMR $\left(400 \mathrm{MHz}, \mathrm{CD}_{3} \mathrm{OD}+\mathrm{NaOD}\right), \mathrm{H}: 9.67(\mathrm{~d}, 1 \mathrm{H}), 9.10(\mathrm{~d}, 1 \mathrm{H}), 9.04(\mathrm{~s}, 1 \mathrm{H}), 8.94(\mathrm{~d}, 1 \mathrm{H}), 8.31(\mathrm{t}, 1 \mathrm{H}), 8.25$ $(\mathrm{d}, 1 \mathrm{H}), 8.03(\mathrm{~d}, 1 \mathrm{H}), 7.99(\mathrm{~m}, 1 \mathrm{H}), 7.90(\mathrm{~m}, 1 \mathrm{H}), 7.67(\mathrm{~m}, 1 \mathrm{H}), 7.38(\mathrm{t}, 1 \mathrm{H}), 7.27(\mathrm{~m}, 1 \mathrm{H}), 2.21-2.40(\mathrm{~m}, 4 \mathrm{H})$, $1.06(\mathrm{~m}, 10 \mathrm{H}), 0.95(\mathrm{~m}, 6 \mathrm{H}), 0.82(\mathrm{~m}, 3 \mathrm{H}), 0.73(\mathrm{~m}, 4 \mathrm{H}), 0.67(\mathrm{~m}, 3 \mathrm{H}), 0.40(\mathrm{~m}, 4 \mathrm{H})$. Elemental analysis [\%, $\mathrm{C}_{41} \mathrm{H}_{48} \mathrm{~N}_{6} \mathrm{O}_{4} \mathrm{RuS}_{2}$ calculated] C, 54.84(54.84), $\mathrm{H}, 5.16(5.20), \mathrm{N}, 9.36(9.37) .{ }^{13} \mathrm{C}$ NMR $\left(125 \mathrm{MHz}, \mathrm{CDCl}_{3}\right): 170.25$, $170.67,164.32,160.64,155.76,153.83,153.68,152.52$, 144.86, 144.74, 144.68, 134.44, 134.40, 134.34, 133.94, $127.37,127.30,126.79,12.69,126.50,126.42,123.63,123.57,79.74,61.52,36.73,35.51,29.51,29.45,28.70$, $28.59,28.49,24.09,23.57,14.75,14.70,14.35,11.13,11.09$. The main IR absorption peaks of the dye (v/cm-1): 3410(s), 2962(m), 2100(s), 1720(s), 1569(s), 1529(w), 1453(m), 1405(m), 1367(s), 1233(m), 1023(s), 889(s), 793(s).

\subsection{The preparation of dye-sensitized solar cell}

In order to detect efficiency and application prospect of the target dye molecule, we prepared the dye-sensitized solar cell using this dye. A double layer film of interconnected $\mathrm{TiO}_{2}$ particles was used as mesoporous anode electrode(light absorbing layer). The button membrane consist of a $7 \mu \mathrm{m}$ thick film of 20 -nm-sized $\mathrm{TiO}_{2}$ particles, the upper membrance consist of a $5 \mu \mathrm{m}$ thick film of 400 -nm-sized $\mathrm{TiO}_{2}$ particles.

The preparation procedures of $\mathrm{TiO}_{2}$ nanocrystalline and nanostructure $\mathrm{TiO}_{2}$ with double membranes electrode has been reported in the literature procedure.( Wang P., 2003)

The well-prepared nanostructure $\mathrm{TiO}_{2}$ electrode with double membranes was strained by immersing it into a dye solution containing the above presented molecular structure(I) of ruthenium dye $(300 \mu \mathrm{m})$, cheno $(300 \mu \mathrm{m})$ in a mixture of acetonitrile and tert-butanol (volume ratio) for 12 hours. So the dye can absorb on the electrode and ensure to have a coverage of over $90 \%$. Then the glass electrode nano-platinum and nanostructure electrode $\mathrm{TiO}_{2}$ with double membranes were separated by a $30 \mu \mathrm{m}$ thick holt-melt gasket and sealed up by heating. Finally, the electrolyte was injected the hole between two electrodes, and we got the wanted solar cell. The Fig.1 is the photocurrent action spectra (IPCE) and J-V characteristic of this solar cell.

\section{Result and discussion}

Compared to the traditional synthetic route, the synthetic route discussed in this thesis didn't use the procedures of lithiation and tination, and the reaction conditions was more mild, providing a novel method for the industrialization of the dye-sensitized solar cell. From the Fig.1, we can see that the value of IPCE was to $7 \%$ 
under the rapid sensitization, not inferior to the other dyes. Its short-circuit current was to $15 \mathrm{~mA}$, and this figure has been up to the standard of our daily life.

\section{References}

Brian O'regan, Michael Grätzel. (1991). A low-cost, high-efficiency solar cell based on dye-senstized colloidal $\mathrm{TiO}_{2}$ films. Nature, 736-737. DOI:10.1038/353737a0.

Gao F. F., Wang Y., et al. (2008). A new heteroleptic ruthenium sensitizer enhances the absorptivity of mesoporous titania film for a high efficiency dye-sensitized solar cell. Chem .Commun., 2635-2637. DOI: $10.1039 / \mathrm{b} 802909 \mathrm{a}$.

Grätzel M. (2008). Enhance the Optical Absorptivity of Nanocrystalline $\mathrm{TiO}_{2}$ Film with High Molar Extinction Coefficient Ruthenium Sensitizers for High Performance Dye-Sensitized Solar Cells . J. Am. Chem. Soc., 130, 10720-10728. DOI: $10.1021 /$ ja 801942 j.

Nazeeruddin M. K., DeAngelis F., et al. Combined experimental and DFT-TDDFT computational study of photoelectrochemical cell ruthenium sensitizers. J. Am. Chem. Soc., 2005, 127, 16835-16847. DOI: $10.1021 / \mathrm{ja} 0524671$.

Plater M. J., Kemp S., et al. (2000). Heterocyclic free radicals. Part 1. 4,5-diazafluorene derivatives of Koelsch's free radical: an EPR and metal-ion complexation study. J. Chem. Soc.,Perkin Trans. 1, 971-979. DOI:10.1039/A909109B.

Su H. C., Chen H. F., et al. (2008). Solid-state white light-emitting electrochemical cells using iridium-based cationic transition metal complexes. J. Am. Chem. Soc., 130, 3413-3419. DOI:10.1021/ja076051e.

Wang P., Zakeeruddin S. M., et al. (2003). Stable new sensitizer with improved light harvesting for nanocrystalline dye-sensitized solar cells. Adv. Mater., 15, 2101.DOI:10.1002/adma.200400039.

Wang P.. (2003). Interfacial self-assembled fabrication of petal-like CdS/dodecylamine hybrids toward enhanced photoluminescence. J. Phys. Chem. B, 107, 14336-1433. DOI: 10.1021/jp0365965.

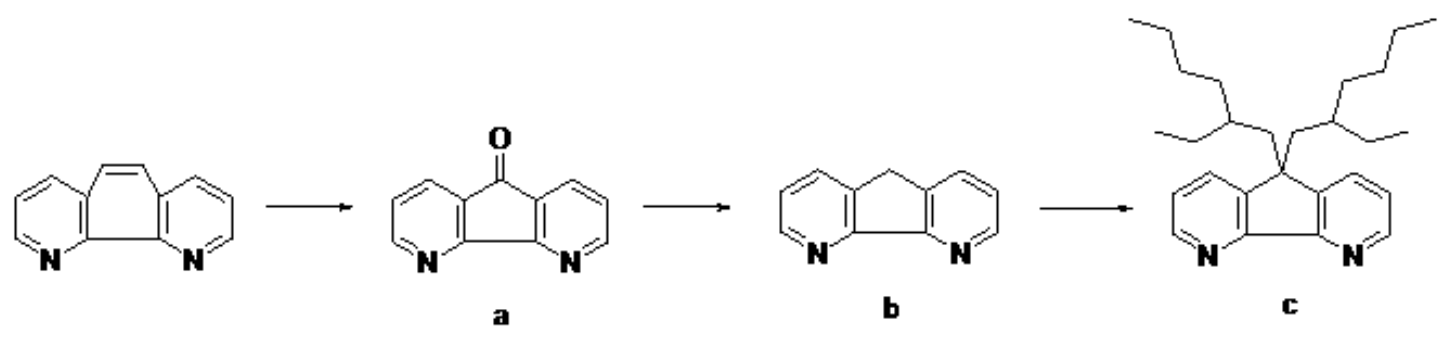

Scheme 1

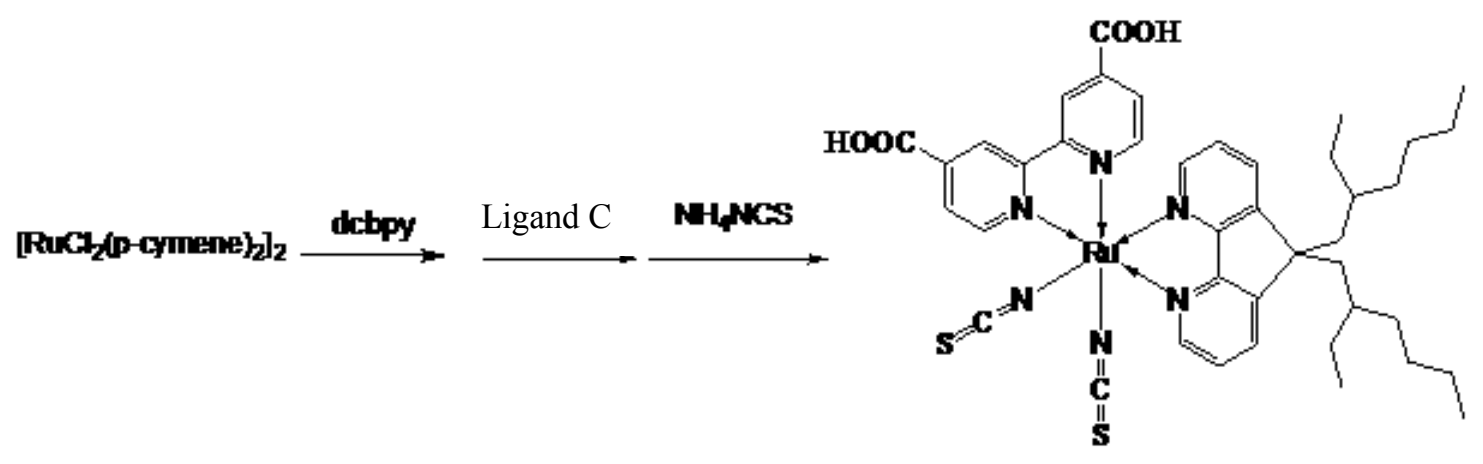

Scheme 2 

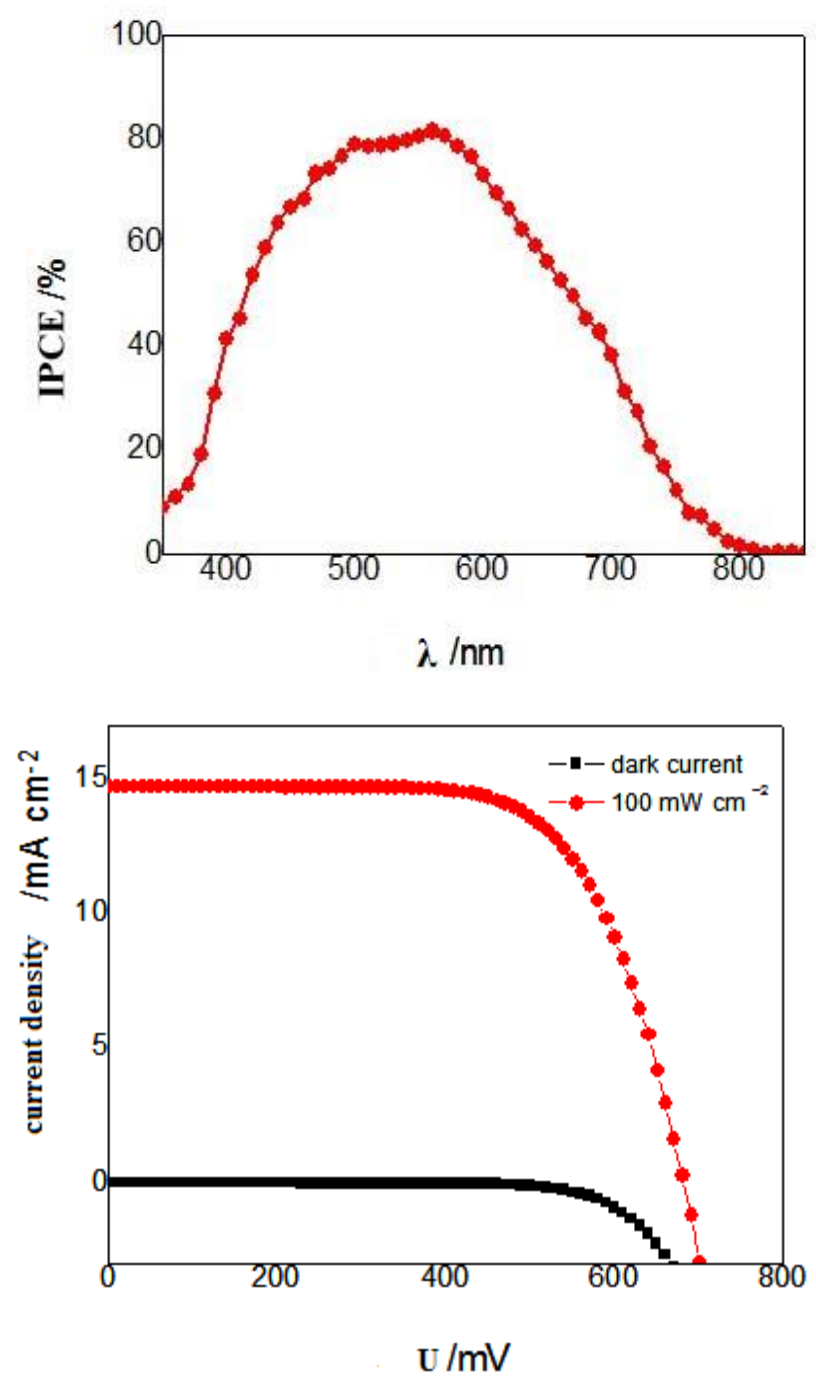

Figure 1. (right) Photocurrent action spectrum the DSC tested with a mask: $0.158 \mathrm{~cm}^{2}$ sunlight $\left(100 \mathrm{~mW} \mathrm{~cm}^{-2}\right)$.

(left) J-V characteristic of the DSC with the sensitizer under the illumination of AM 1.5G full 